УДК 339.56

JEL classification: E44, F40, G15

Грінько I. М.

канд. економ. наук., доцент ORCID ID: 0000-0002-8948-5686

Національний технічний університет Украӥни «Київський політехнічний інститут імені Ігоря Сікорського»

\title{
ВИЗНАЧЕННЯ ОПТИМАЛЬНОЇ ДОКУМЕНТАРНОЇ ФОРМИ МІЖНАРОДНИХ РОЗРАХУНКІВ У ЗОВНІШНЬОЕКОНОМІЧНІЙ ДІЯЛЬНОСТІ ПІДПРИСМСТВ
}

\section{DETERMINATION OF OPTIMAL DOCUMENTARY FORM OF INTERNATIONAL SETTLEMENTS IN FOREIGN ECONOMIC ACTIVITY OF ENTERPRISES}

Статтю присвячено визначенню та вибору оптимальної документарної форми міжнародних розрахунків у здійсненні зовнішньоекономічної діяльності між контрагентами різних країн світу. Систематизовано документарні та недокументарні форми міжнародних розрахунків $i$ представлено їх наочно. Розглянуто сутність та види документарного акредитива та інкасо. Обгрунтовано, щзо на вибір документарної форми міжнародних розрахунків впливає розвиток зовнішньоекономічної діяльності краӥни контрагента. На підставі иього обтрунтування проаналізовано стан зовнішньоекономічної діяльності України з 2008-2019 рр. завдяки таким показникам як: експорт, імпорт, зовнішньоторговельний оборот. Проаналізовано динаміку валютної структури розрахунків платіжного балансу України з 2010-2020 (I квартал) рр., оскільки особливість проведення міжнародних розрахунків у зовнішньоекономічній діяльності підприємств відбувається з використанням різних валют світу. Обгрунтовано, щуо на системність вибору документарної форми міжнародних розрахунків впливають переваги та недоліки у застосуванні конкретної форми розрахунку як експортерами, так й імпортерами та платоспроможність контрагентів зокрема. Узагальнено особливості вибору документарних форм міжнародних розрахунків контрагентами враховуючи їхній фінансовий стан. Обтрунтовано методику визначення оптимальної документарної форми міжнародних розрахунків, яка трунтується на розрахункові двох основних показників: термін надходження товарів від експортера до імпортера; термін виконання імпортером боргових зобов'язань перед експортером. Охарактеризовано зміну фінансового стану підприємств контрагентів у виборі документарної форми міжнародних розрахунку. Перспективним напрямом подальших досліджень є виявлення переваг та недоліків вибору недокументарних форм міжнародних розрахунків і умови їх застосування для експортера та імпортера у проведенні зовнішньоекономічної діяльності підприємств.

Ключові слова: міжнародні розрахунки, контрагенти, зовнішньоекономічна діяльність, міжнародні угоди, документарна форма, акредитив, інкасо. 
The article is devoted to the definition and selection of the optimal documentary form of international settlements in the implementation of foreign economic activity between counterparties from different countries of the world. Documentary and nondocumentary forms of international settlements are systematized and presented visually. The essence and types of letter of credit and collection are considered. It is substantiated that the choice of the documentary form of international settlements is influenced by the development of foreign economic activity of the counterparty country. Based on this justification, the state of Ukraine's foreign economic activity from 2008-2019 is analysed due to such indicators as: exports, imports, foreign trade turnover. The dynamics of the currency structure of balance of payments calculations of Ukraine from 2010-2020 (I quarter) is analysed, as the peculiarity of international settlements in foreign economic activity of enterprises is with the use of different currencies of the world. It is substantiated that the systematic choice of the documentary form of international settlements is influenced by the advantages and disadvantages of using a specific form of payment by both exporters and importers and the solvency of counterparties in particular. The peculiarities of the choice of documentary forms of international settlements by counterparties taking into account their financial condition are generalized. The method of determining the optimal documentary form of international settlements, which is based on the calculation of two main indicators: the term of receipt of goods from exporter to importer; the term of fulfilment by the importer of debt obligations to the exporter. The change of a financial condition of the enterprises of counterparties in a choice of a documentary form of the international calculations is characterized. A promising area of further research is to identify the advantages and disadvantages of choosing non-documentary forms of international settlements and the conditions of their application for exporters and importers in conducting foreign economic activity of enterprises.

Keywords: international settlements, counterparties, foreign economic activity, international agreements, documentary form, letter of credit, collection form of payment.

Вступ. Здійснення зовнішньоекономічної діяльності є необхідним інструментом виробничо-комерційної діяльності будь-якого підприємства як іноземного, так і вітчизняного. Складна система проведення та вибору форм міжнародних розрахунків може стримувати розвиток зовнішньоекономічної діяльності українських підприємств, і у тому числі країни в цілому. У процесі укладення зовнішньоторговельних угод в міжнародній торгівлі важливим $\epsilon$ врахування інтересів обох контрагентів. Тому, одним із ключових аспектів $\epsilon$ розробка та узгодження сучасних договірних зобов'язань у проведенні міжнародних розрахунків та визначенні оптимального їх вибору з урахуванням переваг та недоліків як для експортера, так й імпортера. При оптимальному виборі документарної, або не документарної форми міжнародних розрахунків актуальним $\epsilon$ врахування гарантії своєчасного та повного надходження коштів на рахунок постачальника (експортера) та забезпечення належного рівня взаємного i банківського контролю за виконанням боргових зобов'язань покупцем (імпортером) за поставлені йому товари чи надані послуги. Відповідно, визначення оптимальної документарної 
форми розрахунків у міжнародній торгівлі між контрагентами $\epsilon$ важливим науковим завданням, у цьому й полягає доцільність обраної актуальної теми дослідження.

Внесок у розвиток особливостей та специфікації вибору форм міжнародних розрахунків українськими підприємствами під час здійснення їхньої зовнішньоекономічної діяльності присвятили свої праці вітчизняні науковці, такі як: О. М. Гнезділова [1]; В. В. Дячек, О. Д. Колосовська, В. С. Оніщенко [2]; Н. В. Кудлаєва, О. Д. Онуфрак [3]; Л. Л. Носач, К. Ю. Величко [4]; І. В. Тюха, Р. В. Рудницький [5]; Г. С. Фединяк [6] та інші. У наукових працях $[1 ; 2 ; 4 ; 5]$ вчені пропонують свої методики щодо вибору міжнародних форм розрахунків та обгрунтовують необхідність їх системного оптимального вибору для забезпечення в майбутньому обрання компромісного варіанту міжнародної угоди. В роботі [7] науковці детально досліджують мінімізацію ризиків при веденні зовнішньоекономічної діяльності вітчизняними підприємствами, які впливають на вибір міжнародної форми розрахунку. Особливої уваги заслуговує праця зарубіжних вчених П. Кругмана, М. Обстфельда, М. Мельца [8], в якій вдало обгрунтовується вплив не лише економічного розвитку, а й політичної стабільності країни на вибір форми міжнародних розрахунків контрагентом.

Постановка завдання. Метою статті $€$ розвиток теоретикометодичних та науково-практичних аспектів визначення оптимальної документарної форми міжнародних розрахунків у зовнішньоекономічній діяльності підприємств. Постановка мети дослідження задля iї досягнення обумовила вирішення наступних завдань: 1) розглянути сутність та види документарних форм розрахунків; 2) обгрунтувати вплив розвитку зовнішньоекономічної діяльності країни на вибір документарної форми міжнародних розрахунків контрагентом та здійснити аналіз основних показників зовнішньоекономічної діяльності України; 3) проаналізувати динаміку валютної структури розрахунків поточного рахунку платіжного балансу, оскільки особливість проведення міжнародних розрахунків полягає у тому, що вони здійснюються в різних валютах; 4) виявити переваги та недоліки застосування документарних форм міжнародних розрахунків для експортера та імпортера; 5) узагальнити особливості вибору документарних форм міжнародних розрахунків контрагентами враховуючи їхній фінансовий стан.

Методологія. Методологічною основою слугували наукові праці відомих вчених, статистичні дані офіційних сайтів, нормативно-правові документи тощо. У дослідженні застосовано методи наукового пізнання, конкретизації, аналізу та синтезу, економіко-математичний, економіко-статистичний, графічний методи. 
Результати дослідження. В укладенні міжнародних угод українські підприємці зазвичай обирають наступні форми розрахунків для здійснення зовнішньоекономічній діяльності 3 іноземними контрагентами, такі як: документарний акредитив, інкасо, відкритий рахунок, аванс. Окрім зазначених, в інших країнах світу популярними в укладенні міжнародних угод $\epsilon$ розрахунки векселями та чеками, банківський переказ, банківська гарантія. Варто зазначити, що у зв'язку 3 не розвиненою технічно-організаційно базою розрахунки чеками та векселями не знайшли широкого застосування у вітчизняному підприємницькому секторі.

Документарними формами розрахунків є акредитив та інкасо, а до недокументарних форм відносяться усі інші зазначені вище форми міжнародних розрахунків, які також представлені на рис. 1.

\begin{tabular}{|l|l|}
\hline \multicolumn{2}{|c|}{ ФОРМИ МІЖНАРОДНИХ РОЗРАХУНКІВ } \\
\hline НЕДОКУМЕНТАРНІ ФОРМИ \\
\hline- Авансований платіж \\
\hline $\begin{array}{l}\text { Платіж на відкритий } \\
\text { рахунок }\end{array}$ \\
\hline- Банківський переказ \\
\hline- Розрахунковий чек \\
\hline- Векредитив \\
\hline - Вексель \\
\hline- Банківська гарантія \\
\hline
\end{tabular}

Рисунок 1 - Форми міжнародних розрахунків у зовнішньоекономічній діяльності контрагентів.

Джерело: систематизовано на основі наукових пращь $[2$, c. $73 ; 4$, c. $40-41]$.

Документарний акредитив має вигляд заповненого на формалізованому бланку договір, у якому банк, що відкриває акредитив, бере на себе зобов'язання здійснити за розпорядженням та за рахунок покупця платіж зазначеної у ньому суми третій особі, або акцептувати трату проти подання продавцем комплекту документів, які підтверджують поставку товару [2, c. 74]. Видами документарного акредитиву $\epsilon$ наступні: відкличний, безвідкличний, безвідкличний підтверджений, безвідкличний не підтверджений, покритий, непокритий. 
Інкасо - це торгова угода, за якою експортер дає доручення своєму банку отримати оплату за поставлені товари чи послуги від імпортера за умови, що банк експортера має відправити відповідні супроводжуючі документи в банк імпортера разом з інструкціями по оплаті $[4$, с. 41]. Існують такі види інкасо як: чисте (інкасо фінансових документів, які не супроводжується комерційними документами) та документарне (інкасо фінансових документів, які супроводжується комерційними документами інкасо, або інкасо тільки комерційних документів).

Українські підприємці, які здійснюють зовнішньоекономічну діяльність $з$ іноземними контрагентами зазвичай із документарних та недокументарних форм міжнародних розрахунків надають перевагу документарному акредитиву. Оскільки, при здійсненні розрахунків за експортними операціями особливо із контрагентами, які знаходяться на території країн третього світу у вітчизняних підприємців виникає сумнів щодо платоспроможності таких країн-партнерів.

Проведення міжнародних розрахункових операцій між контрагентами різних країн світу відбувається згідно грошових вимог та зобов'язань, які виникають між ними під час підписання та дотримання міжнародних угод. Тому, міжнародні розрахунки на відміну від внутрішніх регулюються не лише національною нормативно-правовою базою $[9 ; 10 ; 11]$, а й міжнародними законами, уніфікованими правилами та звичаями [12;13].

Зовнішньоекономічна діяльність пов'язана з системним вибором міжнародних форм розрахунків та здійснюється між різними суб'єктами, як державами, так і суб'єктами господарювання чи іншими юридичними особами, тобто експортерами та імпортерами, що знаходяться на території різних країн світу. Аналізуючи розвиток зовнішньоекономічної діяльності України, отримано динаміку основних макроекономічних показників за останні дванадцять років, а саме темпів приросту експорту та імпорту (рис. 2).

Виходячи 3 отриманих результатів уже після проведеного розрахунку темпів приросту, можна відзначити, що у 2009 році в Україні мав негативні показники абсолютний ланцюговий приріст експорту та імпорту. 32010 року показники абсолютного приросту експорту та імпорту стабілізувалися, але починаючи із 2012 року негативна тенденція спаду оновилася. Так, показники експорту та імпорту України у 2015 році майже досягли кризового рівня 2009 року, хоча й у 2016 році спостерігаємо незначне поліпшення основних показників зовнішньоекономічної діяльності. Зовнішньоторговельний обсяг у 2015 році становив 89,2 млрд дол. США [14] та сягнув найнижчої позначки за останні 12 років аналізованого періоду. 32016 
року (90,4 млрд дол. США) спостерігається не значний ріст цього показника, і порівняно з 2019 роком зріс на 15 млрд дол. США [14].

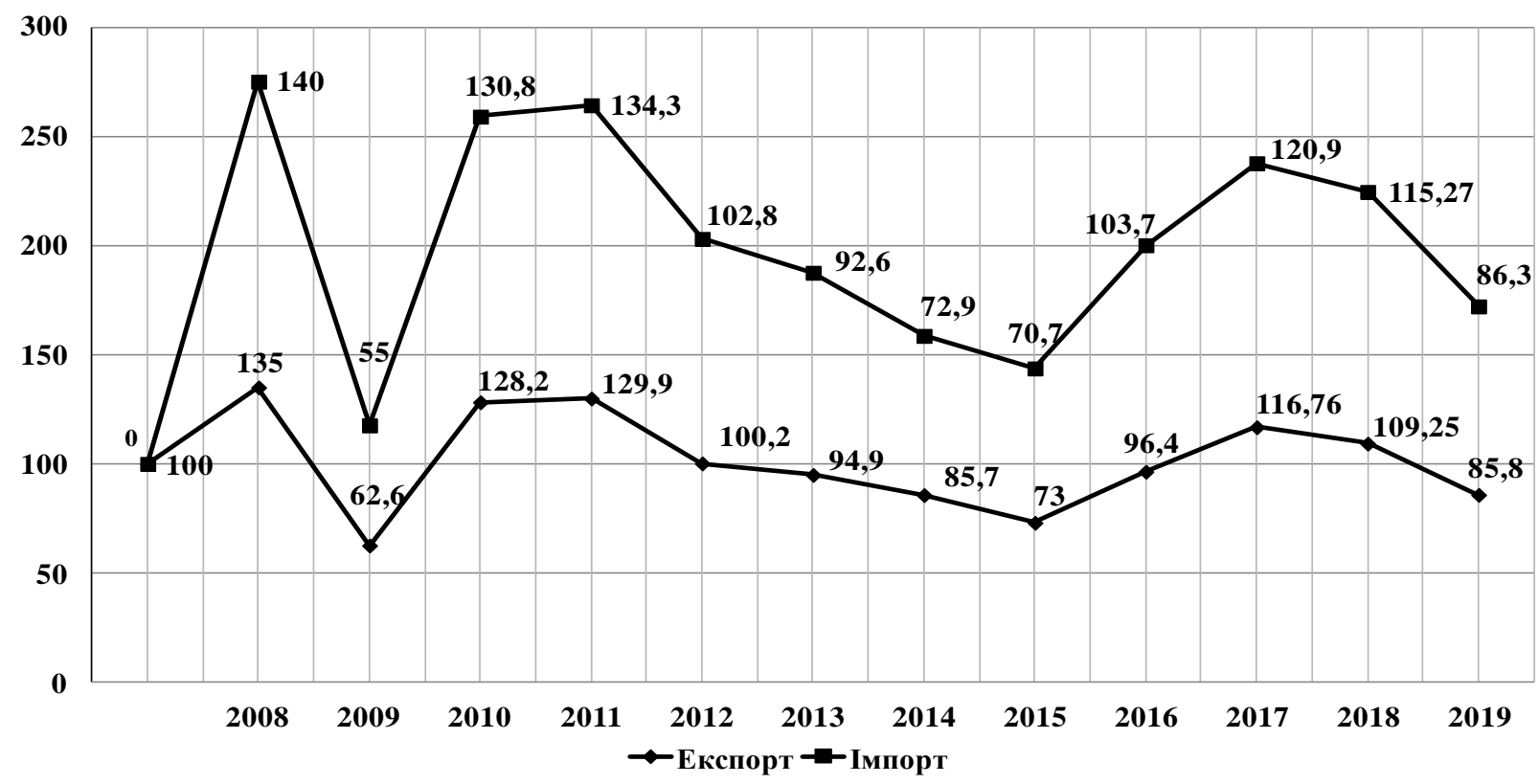

Рисунок 2 - Динаміка показників експорту та імпорту України за 2008-2019 pр. (у \% до попереднього періоду). Джерело: розраховано та побудовано за даними [14]

Особливість міжнародних розрахунків між контрагентами полягає у тому, що оплата за товари та послуги здійснюється у різних валютах світу. Відповідно, на ефективність проведення розрахунків та розвиток зовнішньоекономічної діяльності підприємств впливає динаміка валютних курсів. Ефективні міжнародні товарно-грошові відносини між країнами світу досягаються за умови вільної конвертованості національної валюти на валюту іншої країни, тобто безперешкодного руху коштів та переміщення капіталів. Українська гривня не $є$ вільно конвертованою валютою, і це підтверджує офіційна статистика Національного банку України щодо динаміка валютної структури розрахунків поточного рахунку платіжного балансу (табл. 1).

Аналіз валютної структури розрахунків за операціями поточного рахунку платіжного балансу за останні 10 років свідчить, що долар США займає найбільшу частку за статтями надходжень і виплат. Наприклад, середне значення надходжень у доларах за 10 років становило $72,3 \%$, то виплат - $62,6 \%$ в середньому [15]. Простежуючи динаміку зміни структури, можна зауважити, що надходження у доларах мають тенденцію до зростання, тоді як частка виплат за останні роки поступово зменшилася на 14,3\% [15]. Надходження в російських рублях зростали до 2013 року, а виплати до 2012 року, то після цих років прослідковується тенденція поступового спаду до першого кварталу 2020 року включно [15]. 
Таблиця 1 - Валютна структура розрахунків за операціями поточного рахунку платіжного балансу (у \% до загального обсягу)

\begin{tabular}{|c|c|c|c|c|c|c|c|c|c|c|c|c|c|}
\hline \multirow{2}{*}{$\begin{array}{l}\text { № } \\
\Pi / \Pi\end{array}$} & \multirow{2}{*}{ Валюта } & \multirow{2}{*}{$\begin{array}{c}\text { Статті } \\
\text { балансу } \\
\end{array}$} & \multicolumn{11}{|c|}{ Роки } \\
\hline & & & 2010 & 2011 & 2012 & 2013 & 2014 & 2015 & 2016 & 2017 & 2018 & 2019 & 2020 \\
\hline \multirow{2}{*}{1.} & \multirow{2}{*}{$\begin{array}{l}\text { Долар } \\
\text { США }\end{array}$} & Надходження & 73,3 & 72,3 & 73,8 & 69,6 & 70,9 & 72,5 & 73,1 & 73,0 & 72,3 & 72,1 & 68,9 \\
\hline & & Виплати & 69,1 & 66,7 & 66,6 & 65,5 & 66,2 & 62,8 & 55,7 & 56,1 & 54,8 & 53,4 & 53,3 \\
\hline \multirow{2}{*}{2.} & \multirow{2}{*}{$\begin{array}{l}\text { Російський } \\
\text { рубль }\end{array}$} & Надходження & 12,4 & 12,9 & 13,5 & 16,9 & 13,4 & 8,2 & 6,7 & 4,7 & 4,6 & 3,9 & 3,0 \\
\hline & & Виплати & 6,1 & 6,6 & 8,0 & 7,0 & 6,4 & 4,1 & 3,8 & 2,6 & 2,5 & 2,0 & 1,6 \\
\hline \multirow{2}{*}{3.} & \multirow{2}{*}{ Свро } & Надходження & 13,7 & 14,1 & 12,0 & 12,8 & 14,8 & 16,0 & 18,1 & 21,1 & 22,0 & 23,0 & 27,2 \\
\hline & & Виплати & 23,1 & 25,1 & 23,9 & 26,0 & 25,7 & 28,7 & 37,3 & 39,2 & 40,7 & 42,7 & 42,6 \\
\hline \multirow{2}{*}{4.} & \multirow{2}{*}{$\begin{array}{l}\text { Українська } \\
\text { гривня }\end{array}$} & Надходження & 0,1 & 0,2 & 0,1 & 0,2 & 0,3 & 2,1 & 0,2 & 0,1 & 0,2 & 0,2 & 0,2 \\
\hline & & Виплати & 0,2 & 0,1 & 0,1 & 0,1 & 0,3 & 2,4 & 0,1 & 0,1 & 0,1 & 0,1 & 0,1 \\
\hline \multirow{2}{*}{5} & \multirow{2}{*}{$\begin{array}{l}\text { Інші } \\
\text { валюти }\end{array}$} & Надходження & 0,5 & 0,5 & 0,6 & 0,5 & 0,5 & 1,2 & 1,9 & 1,3 & 0,9 & 0,8 & 0,7 \\
\hline & & Виплати & 1,5 & 1,5 & 1,4 & 1,4 & 1,4 & 2,0 & 3,1 & 2,0 & 0,1 & 1,8 & 1,4 \\
\hline
\end{tabular}

Джерело: систематизовано та побудовано на підставі даних [15].

Примітка: "дані представлені за перший квартал 2020 року.

Зазвичай іноземні банки висловлюють відсутність довіри до українських банків та банківської системи зокрема. Відповідно, західними банками встановлюються такі умови обслуговування документарних акредитивів та інкасо, що є не прийнятними та не вигідними для вітчизняних банків. Певний ступінь недовіри щодо економічної, політичної та правової стабільності України існує в країн Західної Свропи, Північної Америки, Японії та інших країн світу 3 високорозвиненою ринковою економікою. Ці регіони враховують підвищений рівень ризику України у зазначених сферах, i у них також виникає певний ступінь не довіри щодо платоспроможності українських партнерів при укладенні міжнародних угод. Тому, зазвичай іноземні партнери надають перевагу документарним формам розрахунку в міжнародних відносинах 3 Україною при проведенні експортно-імпортних операцій.

Проблемними питаннями при виборі документарної форми міжнародних розрахунків $\epsilon$ : фактор часового розриву, тобто відстань на яку здійснюється постачання товару чи надання послуг; недооцінка іноземного партнера (у тому числі, виникнення сумніву щодо його платоспроможності); відмінність у законодавчих базах країн та їх економічна, політична, правова не стабільність, яка притаманна економічному розвитку певних країн світу.

Вибір документарної форми міжнародних розрахунків контрагентами має носити системний характер. Тому, цілком погоджуємося із думкою вчених [4], що системність вибору форми розрахунку дозволить: 1) ретельно дослідити усі переваги та недоліки застосування конкретної форми розрахунку як експортерами, так i 
імпортерами під час здійснення ними зовнішньоекономічної діяльності; 2) оцінити ефективність проведення вибраної оптимальної документарної форми розрахунків, тим самим забезпечивши нормальний рівень платоспроможності та ліквідності підприємства.

Аналізуючи методики визначення оптимального вибору документарної форми у проведенні міжнародних угод різними ученими $[1 ; 2 ; 4 ; 5]$, варто зауважити, що потрібно порівнювати два основних показники - це термін надходження товарів від експортера до імпортера $\left(t_{n t}\right)$, і термін виконання імпортером боргових зобов'язань перед експортером $\left(t_{v z}\right)$ для розрахунку показника вибору форми $\left(k_{v}\right)$. $\mathrm{V}$ табл. 2 представлено характеристику фінансового стану підприємств суб'єктів зовнішньоекономічної діяльності при укладенні міжнародних угод та оптимальному виборі міжнародної форми розрахунків експортером та імпортером. Співвідношення зазначених показників швидкості обороту зобов'язань контрагентів у першу чергу визначають можливості здійснення платежів, тобто рівень поточної платоспроможності кожного із контрагентів. Управляючи наведеними в табл. 2 співвідношеннями можна вплинути на основні параметри фінансового стану підприємств, як експортера, так й імпортера.

Укладаючи міжнародні угоди та при цьому обираючи документарну форму міжнародних розрахунків, варто пам'ятати, що існує пряма залежність значення показника вибору оптимальної форми розрахунків та способу оплати продукції, товарів, робіт чи послуг під час здійснення міжнародної діяльності. Документарна форма розрахунків передбачає великий обсяг роботи із документами, і в основу розрахунків покладено рух товаророзпорядчих документів та операційне оформлення платежів за укладеними зовнішньоекономічними угодами [2, с. 71]. Також ця форма розрахунку потребує тісної взаємодії та співпраці іноземних і українських банків.

Підсумовуючи вище зазначене, варто зауважити, що вибір оптимальної документарної форми розрахунків $\epsilon$ важливою умовою забезпечення ефективного кругообігу коштів у виробничо-комерційній діяльності підприємств, зміцнення їх фінансової, господарської самостійності та забезпечення прибуткової підприємницької діяльності. 
Таблиця 2 - Зміна характеристик фінансового стану підприємств у виборі оптимальної документарної форми міжнародних розрахунків

\begin{tabular}{|c|c|c|}
\hline \multirow{2}{*}{$\begin{array}{l}\text { Співвідношення } \\
\text { показників у } \\
\text { виборі форми } \\
\text { розрахунку }\left(k_{v}\right)\end{array}$} & \multicolumn{2}{|c|}{$\begin{array}{c}\text { Характеристика фінансового стану підприємств } \\
\text { при виборі документарної форми розрахунку }\end{array}$} \\
\hline & $\begin{array}{l}\text { Переваги та недоліки для } \\
\text { експортера }\end{array}$ & $\begin{array}{c}\text { Переваги та недоліки для } \\
\text { імпортера }\end{array}$ \\
\hline$t_{n t} / t_{v z}>1$ & $\begin{array}{c}\text { Дуже гарна та сприятлива } \\
\text { ситуація, але якщо експортер } \\
\text { може забезпечити поточний рівень } \\
\text { платоспроможності до виконання } \\
\text { боргових зобов’язань імпортерів. } \\
\text { Відповідно термін виконання } \\
\text { своїх зобов’язань має } \\
\text { перевищувати термін надходжень } \\
\text { грошових коштів від імпортерів за } \\
\text { надані товари та послуги. }\end{array}$ & $\begin{array}{c}\text { Нестійкий фінансовий стан } \\
\text { підприємства, оскільки } \\
\text { відволікаються кошти із } \\
\text { обороту (особливо при вборі } \\
\text { покритої документарної } \\
\text { акредитивної форми } \\
\text { міжнародних розрахунків). При } \\
\text { цьому термін очікуваних } \\
\text { надходжень від імпорту нижчий } \\
\text { від терміну виконання своїх } \\
\text { боргових зобов'язань перед } \\
\text { експортером. }\end{array}$ \\
\hline$t_{n t} / t_{v z} \rightarrow 1$ & \multicolumn{2}{|c|}{$\begin{array}{c}\text { Взаємовигідний стан при якому досягається ідеальний рівень } \\
\text { платоспроможності підприємств як експортера, так й імпортера; } \\
\text { исока фінансова стійкість підприємств; товари відвантажені вчасно } \\
\text { чи вчасно надані послуги; оплата за них також надходить вчасно. }\end{array}$} \\
\hline$t_{n t} / t_{v z}<1$ & $\begin{array}{c}\text { Критичний стан, коли на тривалий } \\
\text { термін відволікаються кошти } 3 \\
\text { обороту (особливо при виборі } \\
\text { документарної інкасової форми } \\
\text { розрахунку). Тому, фінансова } \\
\text { стійкість підприємства може бути } \\
\text { під загрозою, особливо, коли } \\
\text { грошові кошти у експортера } \\
\text { відсутні та йому необхідно } \\
\text { просити клієнтів про більш ранню } \\
\text { оплату заборгованостей. } \\
\text { Наприклад, обирати вид інструкції } \\
\text { інкасового доручення, який має } \\
\text { назву «вручення документів проти } \\
\text { платежу», що передбачає негайну } \\
\text { оплату поданих документів згідно } \\
\text { інкасо. В інструкції вказується } \\
\text { наступний пункт «платіж за } \\
\text { першим поданням документів». }\end{array}$ & $\begin{array}{c}\text { Нормальний стан, який } \\
\text { передбачає вчасне отримання } \\
\text { товарів чи надання послуг. } \\
\text { Результатом цього є } \\
\text { забезпечення нормального рівня } \\
\text { платоспроможності навіть, якщо } \\
\text { термін виконання зобов’язань } \\
\text { перед експортерам ще не настав. } \\
\text { Наприклад, це може бути один } \\
\text { із видів інструкції інкасового } \\
\text { доручення, що має назву } \\
\text { «вручення документів проти } \\
\text { акцепту». } \\
\text { Тобто, імпортер (трасат) вступає } \\
\text { у володіння товаром ще до } \\
\text { моменту здійснення платежу, } \\
\text { тим самим він має змогу } \\
\text { отриманий товар швидко } \\
\text { продати та за виручені кошти } \\
\text { виконати боргові зобов’язання } \\
\text { перед експортером. }\end{array}$ \\
\hline
\end{tabular}

Джерело: систематизовано та доповнено автором на підставі методик наукових праць вчених [2; 4$].$

Висновок. Проведене дослідження надало можливість вирішити наукову проблематику з розвитку теоретико-методичних та науковопрактичних аспектів визначення оптимальної документарної форми міжнародних розрахунків у зовнішньоекономічній діяльності підприємств в умовах економічної нестабільності, зокрема, узагальнити особливості (переваги та недоліки) вибору документарних форм 
міжнародних розрахунків для експортера та імпортера i зміну фінансового стану контрагентів в укладенні ними міжнародних угод.

Наукова новизна результатів дослідження полягає в узагальненні особливостей (переваг та недоліків) вибору документарних форм міжнародних розрахунків контрагентами враховуючи термін надходження товарів від експортера до імпортера та термін виконання імпортером боргових зобов'язань перед експортером для визначення оптимальної документарної форми розрахунків у зовнішньоекономічній діяльності підприємств.

Перспективним напрямом подальших досліджень має стати виявлення переваг та недоліків вибору недокументарних форм (авансований платіж, платіжна на відкритий рахунок, розрахунок векселями та чеками, банківський переказ, банківська гарантія та інші) міжнародних розрахунків і умови та особливості їх розрахунку для експортера та імпортера у проведенні зовнішньоекономічної діяльності.

\section{Література:}

1. Гнезділова О. М. Оптимізація системи безготівкових розрахунків / Сучасні питання економіки і права. 2011. Вип. 2. С. 100-105.

2. Дячек В. В., Колосовська О. Д., Оніщенко В. С. Особливості використання форм міжнародних розрахунків українськими підприємствами під час здійснення зовнішньоекономічної діяльності / Глобальні та національні проблеми економіки. 2018. Вип. 21. С. 70-76.

3. Кудлаєва Н. В., Онуфрак О. Д. Особливості застосування акредитивної форми міжнародних розрахунків в іноземній валюті. Науковий вісник Міжнародного гуманітарного університету. 2017. Вип. 27 (2). С. 124-128.

4. Носач Л. Л., Величко К. Ю. Системний вибір оптимальної форми міжнародних розрахунків. Бізнес Інформ. 2016. № 10. С. 39-46.

5. Тюха I. В., Рудницький Р. В. Вибір оптимальної форми розрахунків в управлінні зовнішньоекономічною діяльністю підприємств харчової промисловості. Формування ринкових відносин в Україні. 2014. № 10 (161). С. 114-117.

6. Фединяк Г. С. Міжнародно-правове регулювання розрахунків по акредитиву та законодавство України. Вісник Львівського університету. Сер.: Міжнародні відносини. 2016. Вип. 39. С. 120-127.

7. Шуба Т. П., Колосовська О. Д., Оніщенко В. С. Мінімізація ризиків при веденні зовнішньоекономічної діяльності українськими підприємствами. Глобальні та національні проблеми економіки. 2017. № 20. C.93-98. URL: http://globalnational.in.ua/archive/20-2017/20.pdf. Дата звернення: 26.07.2020 p.

8. International Finance: Theory and Policy / Paul R. Krugman, Maurice Obstfeld, Marc Melitz. Global Edition [11th Edition]. Pearson Education Limited, 2018. 808 p.

9. Закон України «Про зовнішньоекономічну діяльність» від 16.04.1991 № 959-XII, 2020. URL: http://zakon5.rada.gov.ua. Дата звернення: 26.07.2020 p.

10. Закон України «Про валюту і валютні операції» Відомості Верховної Ради (BBP), 2018. № 30. URL: https://zakon.rada.gov.ua/laws/show/2473-19. Дата звернення: 26.07.2020 p. 
11. Постанова правління НБУ «Про особливості здійснення деяких валютних операцій» від 23.01.2015 p. № 124. URL: http://zakon0.rada.gov.ua/ laws/show/v0124500-15. Дата звернення: 26.07.2020 p.

12. Правила Міжнародної торгівельної палати «Уніфіковані правила та звичаї для документарних акредитивів» від 01.07.2007 p. № 600. URL: http://consultant.parus.ua/?doc=00GTQ81A59. Дата звернення: 26.07.2020 p.

13. Правила Міжнародної торгівельної палати «Уніфіковані правила по інкасо» від 01.01.1996 p. URL: http://consultant.parus.ua/?doc=04L9NE52EA. Дата звернення: 26.07.2020 p.

14. Зовнішньоекономічна діяльність // Офіційний сайт Державної служби статистики України, 2020. URL: http://www.ukrstat.gov.ua. Дата звернення: 29.07.2020 p.

15. Статистика зовнішнього сектору України за методологією 6-го видання «Керівництва 3 платіжного балансу та міжнародної інвестиційної позиції» // Офіціальний сайт Національного банку України, 2020. URL: https://bank.gov.ua/ua/statistic/sector-external/data-sector-external\#1. Дата звернення: 29.07.2020 p.

\section{References:}

1. Gnezdilova, O.M. (2011), "Optimization of the system of non-cash payments", Modern Issues of Economics and Law, vol. 2, pp. 100-105.

2. Dyachek, V.V. Kolosovska, O.D. and Onischenko, V.S. (2018), "Features for using forms of international calculations by Ukrainian Enterprises for implementation of foreign economic activities", Global and National Problems of Economics, vol. 21, pp. 70-76.

3. Kudlaeva, N.V. and Onufrak, O.D. (2017), "Application features of letter of credit payment method in foreign currency", International Humanitarian University Herald. Economics and Management, vol. 27, pp. 124-128.

4. Nosach, L.L. and Velichko, E.Yu. (2016), "Systematicity of selection of the optimal form of payment for international settlements", Business Inform, vol. 10, pp. 39-46.

5. Tyukha, I.V. and Rudnytsky, R.V. (2014), "Selection of the optimal form of payment in the management of foreign economic activity of food industry enterprises", Formuvannia rynkovykh vidnosyn v Ukraini, vol. 10, pp. 114-117.

6. Fedinyak, G.S (2016), "International legal regulation of letters of credit and legislation of Ukraine", Visnyk Lvivskoho universytetu, Seriia: Mizhnarodni vidnosyny, vol. 39, pp. 120-127.

7. Shuba, T.P. Kolosovskaya, O.D. and Onishchenko, V.S. (2017), Minimization of risks in conducting foreign economic activity by Ukrainian enterprises. Global and National Problems of Economics, vol. 20, pp. 93-98.

8. Krugman, P. Obstfeld, M. and Melitz, M. (2018), International Finance: Theory and Policy, 11th ed., Pearson Education Limited, USA.

9. The Verkhovna Rada of Ukraine (1991), The Law of Ukraine "About foreign economic activity", available at: http://zakon5.rada.gov.ua (Accessed 26 July 2020).

10. The Verkhovna Rada of Ukraine (2018), The Law of Ukraine "About currency and currency transactions", available at: https://zakon.rada.gov.ua/laws/show/2473-19 (Accessed 26 July 2020).

11. National Bank of Ukraine (2015), Resolution of the Board "About features of implementation of some currency operations", available at: http://zakon0.rada.gov.ua/laws/show/v0124500-15 (Accessed 26 July 2020). 
12. International Chamber of Commerce (2007), Rules "Unified rules and customs for documentary letters of credit", available at: http://consultant.parus.ua/?doc=00GTQ81A59 (Accessed 26 July 2020).

13. International Chamber of Commerce (1996), Rules "Unified collection rules", available at: http://consultant.parus.ua/?doc=04L9NE52EA (Accessed 26 July 2020).

14. State Statistics Service of Ukraine (2020), "Foreign economic activity", available at: http://www.ukrstat.gov.ua (Accessed 29 July 2020).

15. National Bank of Ukraine (2020), "Statistics of the external sector of Ukraine", available at: http://bank.gov.ua/ua/statistic/sector-external/data-sector-external\#1 (Accessed 29 July 2020).

УДК 339.13

JEL classification: F20, F60, F63

Кузнсцова К.О.

канд. економ. наук

ORCID ID: 0000-0003-0162-1071

Лютенко Д.Д.

ORCID ID: 0000-0002-3058-1518

Дергачов Є.B.

канд. філос. наук

ORCID ID: 0000-0001-7238-2595

Національний технічний університет Украӥни «Київський політехнічний інститут імені Ігоря Сікорського»

\section{ВИЗНАЧЕННЯ ТЕРИТОРІАЛЬНО-ГЕОГРАФІЧНИХ ПРІОРИТЕТІВ РОЗВИТКУ ЗОВНІШНЬОЕКОНОМІЧНОЇ ДІЯЛЬНОСТІ ПІДПРИЕМСТВА НА ПРИКЛАДІ ТОВ «ТРАУ НУТРИШИН УКРАЇНА»}

\section{DETERMINATION OF TERRITORIAL-GEOGRAPHICAL PRIORITIES OF THE FOREIGN ECONOMIC ACTIVITY OF THE ENTERPRISE ON THE EXAMPLE OF TROUW NUTRITION UKRAINE LLC}

Глобалізачія світогосподарських прочесів призвела до необхідності активізачіі зовнішньоекономічних відносин між державами на різних рівнях. Суб'єкти господарювання використовують таку можливість для розширення географії власного збуту продукиії та придбання іноземних сировинних матеріалів. Дослідження теоретичних аспектів розширення зовнішньоекономічної діяльності підприємства, враховуючи галузеві особливості, показало, щьо чітко визначений та детально обтрунтований вибір ринку збуту, дозволить підвищити показники ефективності господарської діяльності, завантажити виробничі потужності в повному обсязі, та покращити положення підприсмства на світовому ринку. У даній науковій статті обтрунтовано актуальність розроблення теоретикопрактичних рекомендацій щзодо удосконалення процесу формування стратегії розвитку зовнішньоекономічної діяльності підприємства. Акцентовано увагу на визначенні територіально-географічних пріоритетів. Проаналізовано основні передумови 